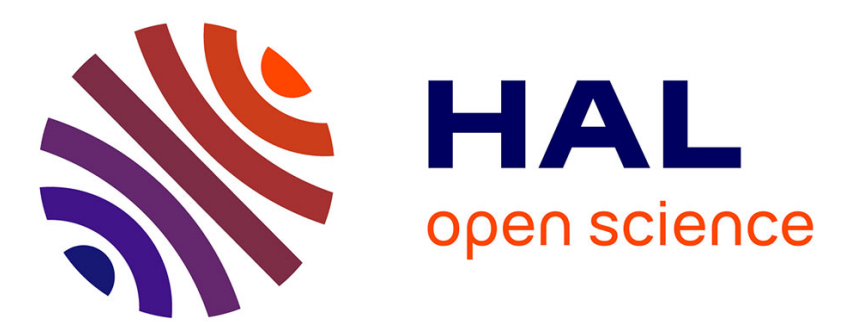

\title{
Genetic variability in intergenic spacers of ribosomal DNA in Pisolithus isolates associated with pine, eucalyptus and Afzelia in lowland Kenyan forests
}

\author{
F. Martin, Christine Delaruelle, M. Ivory
}

\section{- To cite this version:}

F. Martin, Christine Delaruelle, M. Ivory. Genetic variability in intergenic spacers of ribosomal DNA in Pisolithus isolates associated with pine, eucalyptus and Afzelia in lowland Kenyan forests. New Phytologist, 1998, 139, pp.341-352. hal-02688390

\section{HAL Id: hal-02688390 \\ https: / hal.inrae.fr/hal-02688390}

Submitted on 1 Jun 2020

HAL is a multi-disciplinary open access archive for the deposit and dissemination of scientific research documents, whether they are published or not. The documents may come from teaching and research institutions in France or abroad, or from public or private research centers.
L'archive ouverte pluridisciplinaire HAL, est destinée au dépôt et à la diffusion de documents scientifiques de niveau recherche, publiés ou non, émanant des établissements d'enseignement et de recherche français ou étrangers, des laboratoires publics ou privés.

$$
\text { Copyright }
$$




\title{
Genetic variability in intergenic spacers of ribosomal DNA in Pisolithus isolates associated with pine, eucalyptus and Afzelia in lowland Kenyan forests
}

\author{
By FRANCIS MARTIN ${ }^{1 *}$, CHRISTINE DELARUELLE ${ }^{1}$ \\ AND MIKE IVORY ${ }^{2}$ \\ ${ }^{1}$ Equipe de Microbiologie Forestière, Institut National de la Recherche Agronomique, \\ Centre de Recherches de Nancy, F-54280 Champenoux, France \\ ${ }^{2}$ Queensland Forestry Research, Institute, 80 Meier's Road, Indooroopilly, \\ Queensland 4068, Australia
}

(Received May 1997 ; accepted 26 February 1998)

\begin{abstract}
SUMMARY
Basidiocarps of Pisolithus associated with indigenous (Afzelia quanzensis Welw.) and introduced (Pinus caribaea Mor. and Eucalyptus camaldulensis Dehnh.) hosts in the lowland forests of the Coast Province of Kenya are morphologically distinct. Genetic variability among 52 Pisolithus basidiocarps, collected beneath the various host plants, was examined based on sequence polymorphism within the internal transcribed spacer (ITS) and intergenic spacer (IGS1) of ribosomal DNA genes. Variability in ITS and IGS1 sequences indicated that the three host-associated morphotypes were genetically different. Consensus trees generated by bootstrap analysis of sequence data of Pisolithus isolates from Australia and Kenya are polyphyletic and strongly suggest that the three different morphotypes/genotypes present in Kenya represent separate biological species. In addition, our data indicate that little genetic exchange occurs in silva between these species.
\end{abstract}

Key words: Afzelia, ectomycorrhizal fungus, eucalypt, internal transcribed spacer, intergenic spacer, pine, Pisolithus, ribosomal DNA.

\section{INTRODUCTION}

Although considerable variation exists in terms of basidiocarp, spore and isolated mycelium morphology, taxa within the genus Pisolithus are widely regarded as conspecific (Watling et al., 1995). However, distinct Pisolithus species, including $P$. aurantioscabrosus Watling et al., P. kisslingi E. Fisch, P. microcarpus (Cke. \& Mass.) G. Cunn, P. pusillum Pat. and P. tinctorius (Pers.) Coker \& Couch [Syn. : P. arhizus (Scop. per Pers.) Rauschert] have been described based on distinctive basiocarp and basidiospore morphology (Cunningham, 1942; Watling et al., 1995).

Large variations in enzyme activity (Ho, 1987), protein patterns (Burgess, Malajczuk \& Dell, 1995), rDNA sequence (Anderson, Chambers \& Cairney, 1998), mycorrhizal ability (Tonkin, Malajczuk \&

* To whom correspondence should be addressed.

E-mail:fmartin@nancy.inra.fr
McComb, 1989; Lamhamedi et al., 1990) and the morphology of basidiocarps and basidiospores (Burgess, Dell \& Malajczuk, 1994) of P. tinctorius isolates have been reported, suggesting that several biological species can be recognized within the group currently described as P. tinctorius (Bronchart, Calogne \& Demoulin, 1975; Calonge \& Demoulin, 1975; Burgess et al., 1995; Watling et al., 1995). The occurrence of a tetrapolar mating system is seen as further evidence that several biological species exist within the current $P$. tinctorius grouping (Kope \& Fortin, 1990). Previous studies have stressed that host and geographical origin of isolates may play significant roles in this variability (Marx, 1980; Malajczuk, Lapeyrie \& Garbaye, 1990; Burgess et al., 1994).

P. tinctorius has a world-wide distribution and has been found in a range of habitats including roadside areas, orchard and forest sites, as well as eroded and mine-site soils (Marx, 1977). It is an early colonizer 

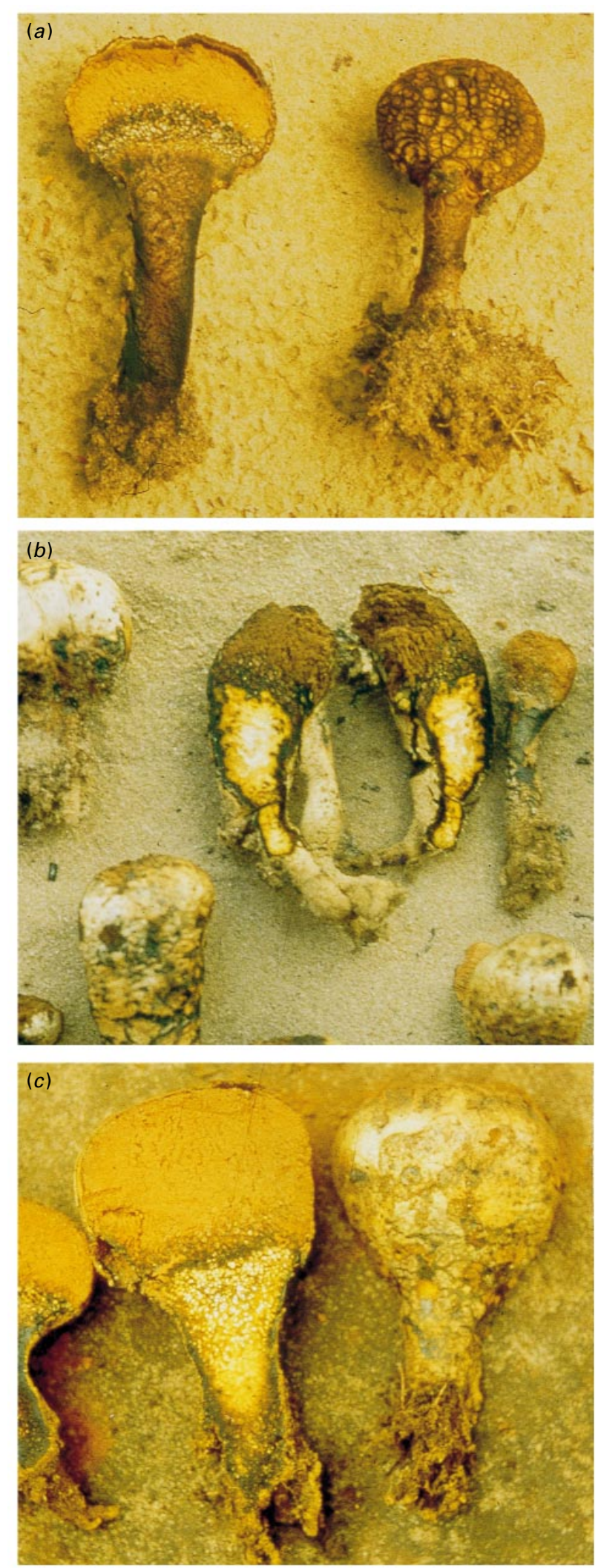

Figure 1. Mature basidiocarps of Pisolithus associated to (a) Afzelia quanzensis, (b) Eucalyptus camaldulensis, and (c) Pinus caribaea collected in the Coast Province of Kenya demonstrating the large variation in form. Magnification: $(a), \times 0.4 ;(b), \times 0.6 ;(c), \times 0.33$.

and has been demonstrated to be a very successful symbiotic partner of a wide range of gymnosperms and angiosperms (Marx, 1977; Cairney \& Chambers
1997). This fungus has potential for practical application in afforestation programmes with growth increases following inoculation reported for pines and eucalypts (Marx, Bryan \& Cordell, 1977; Garbaye, Delwaulle \& Diangana, 1988; Malajczuk et al., 1994). Growth responses of Eucalyptus and Pinus spp. to inoculation with $P$. tinctorius are, however, variable and strongly influenced by fungal genotype (Tonkin et al., 1989; Burgess et al., 1994; Cairney \& Chambers 1997). A thorough examination of phylogeny with $P$. tinctorius and related biological species will probably reveal a genetic basis for differential host specificity and growth response of inoculated plants.

In the Coast Province of Kenya, woodlands of Miombo-like vegetation comprise mainly legume trees of the Caesalpinioideae (e.g. Afzelia quanzensis Welw., Brachystegia spiciformis Benth., Fulbernardia magnistipulata (Harms.) Troupin). Large plantations of Pinus caribaea Mor. and Eucalyptus camaldulensis Dehnh. have also been established in Kenya since 1900, mainly in upland areas. Pisolithus appears to associate with pines, eucalypts, and a native leguminous tree ( $A$. quanzensis). The basidiocarps exhibit considerable morphological variation and are separable into three distinct morphotypes (Fig. 1), each associated with only one of the above hosts (Ivory et al., 1996).

The present study aimed to provide comparative information on the genetic variability and phylogenetic relationships of the three distinct Pisolithus morphotypes found in Kenya. RFLP and sequencing of the intergenic spacers (ITS, IGS1) of the rDNA gene complex of Pisolithus collected beneath $A$. quanzensis, $P$. caribaea and E. camaldulensis were undertaken because these regions are known to be variable at the inter- and intraspecific level (Gardes et al., 1991; Henrion, Le Tacon \& Martin, 1992; Appel \& Gordon, 1996; Kretzer et al., 1996). In addition, ITS region sequences can diagnose phylogenetic relationships at many phylogenetic levels (Hershkovitz \& Lewis, 1996). Our sampling identified three distinct RFLP haplotypes, each specific to a single host. Pairwise comparison of ITS and IGS1 nucleotide sequences between these haplotypes indicates that divergence among them is extensive and suggest that different Pisolithus species are present in the study area.

\section{MATERIALS AND METHODS}

\section{Sites and source of collections}

Basidiocarps of Pisolithus tinctorius were collected in 1993, 1994 and 1995 in Kenya from all its known habitats in the indigenous ectomycorrhizal forests in the lowland coastal region at Arabuko-Sokoke Forest Reserve, in $P$. caribaea and $E$. camaldulensis plantations at Gede Forest Station and the pine 


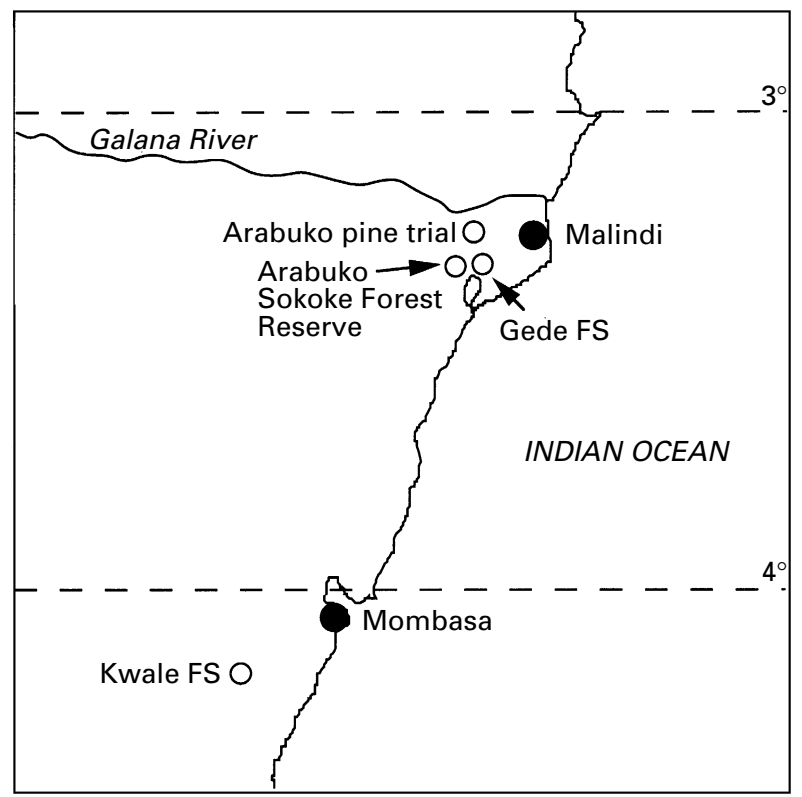

Figure 2. Map of the study area in the Coast Province of Kenya with the sampling sites (O) where Pisolithus basidiocarps were collected. F.S., Forest Station.

mycorrhiza trial sites at Arabuko, Kwale Forest Station (Fig. 2). As far as possible, different areas in each locality and 2-12 basidiocarps in each area were sampled. Samples can thus be ranked from sub- regional $(\sim 100 \mathrm{~km})$ to area $(\sim 100 \mathrm{~m})$ and tree scale $(\sim 10 \mathrm{~m})$. Collection numbers and sampling localities are given in Table 1. The lowland forests occur on infertile, well-drained, deep, sandy soils which are mostly acidic. However, some soils at Gede Forest Station are neutral or slightly alkaline when derived from coral limestone. Mean annual rainfall is $c .1000 \mathrm{~mm}$ and temperature remains fairly constant around $28-32{ }^{\circ} \mathrm{C}$.

Basidiocarp morphological characteristics including size, shape, and colour were recorded for selected isolates and a basidiocarp of each representative morphotype was retained for producing mycelial cultures and then preserved by drying for taxonomic studies using procedures described previously (Ivory, 1987). Immediately after collection, samples (c. $100 \mathrm{mg}$ ) for DNA analysis were excised from the central part of basidiocarp stipes (to avoid contamination by other micro-organisms or spore DNA) and fixed in $1 \mathrm{ml}$ of glycerol/ethanol/water $(30 / 30 / 40)$.

\section{DNA extraction}

DNA was routinely extracted by the cetyltrimethylammonium bromide (CTAB) protocol according to Henrion, Chevalier \& Martin (1994). For recalcitrant

Table 1. Pisolithus collections used in this study with their host plant and rDNA spacer haplotypes

\begin{tabular}{|c|c|c|c|c|}
\hline $\begin{array}{l}\text { Sample } \\
\text { no. }\end{array}$ & $\begin{array}{l}\text { Year } \\
\text { collected }\end{array}$ & Locality & Host & Haplotype \\
\hline 720 & 1993 & Gede F.S. ${ }^{a}$, office yard & Afzelia quanzensis & $\mathrm{A}^{\mathrm{b}}$ \\
\hline 721 & 1993 & Gede F.S., eucalypt plantation & E. camaldulensis & $\mathrm{E}$ \\
\hline 732 & 1993 & Gede F.S., office yard & A. quanzensis & $\mathrm{A}$ \\
\hline 737 & 1993 & $\begin{array}{l}\text { Arabuko-Sokoke, mixed Afzelia } \\
\text { woodland, site } 4\end{array}$ & A. quanzensis & A \\
\hline 758 & 1993 & Gede F.S., plot 4 (planted 1982) & A. quanzensis & $\mathrm{A}$ \\
\hline $824(1-12)^{\mathrm{c}}$ & 1994 & Gede F.S., plot 1 (planted 1974) & A. quanzensis & $\mathrm{A}$ \\
\hline 826 & 1994 & Gede F.S., plot 3 (planted 1982) & A. quanzensis & $\mathrm{A}$ \\
\hline $827(1-2)^{\mathrm{c}}$ & 1994 & Gede F.S., (12 m from plot 3$)$ & A. quanzensis & $\mathrm{A}$ \\
\hline $828(1-2)^{\mathrm{c}}$ & 1994 & Gede F.S., plot 4 (planted 1982) & A. quanzensis & $\mathrm{A}$ \\
\hline 862 & 1994 & Kwale F.S., mycorrhiza trial & P. caribaea & $\mathrm{P}$ \\
\hline 943 & 1994 & Gede F.S., office yard & A. quanzensis & $\mathrm{A}$ \\
\hline 944 & 1994 & $\begin{array}{l}\text { Arabuko-Sokoke, mixed Afzelia } \\
\text { woodland, site } 4\end{array}$ & A. quanzensis & $\mathrm{A}$ \\
\hline $5072(1-5)^{\mathrm{c}}$ & 1995 & Gede F.S., office yard & A. quanzensis & $\mathrm{A}$ \\
\hline $5103(1-5)^{\mathrm{c}}$ & 1995 & Gede F.S., office yard & A. quanzensis & $\mathrm{A}$ \\
\hline $5105(1-3)^{\mathrm{c}}$ & 1995 & Gede F.S., Afzelia plot 2 & A. quanzensis & A \\
\hline $5106(1-4)^{\mathrm{c}}$ & 1995 & Gede F.S., Afzelia plot 3 & A. quanzensis & $\mathrm{A}$ \\
\hline $5107(1-3)^{c}$ & 1995 & Gede F.S., Afzelia plot 4 & A. quanzensis & $\mathrm{A}$ \\
\hline $5110(1-10)^{\mathrm{d}}$ & 1995 & Gede F.S., roadside plantation & E. camaldulensis & $\mathrm{E}$ \\
\hline $5111(1-10)^{\mathrm{e}}$ & 1995 & Arabuko, mycorrhiza trial & P. caribaea & $\mathrm{P}$ \\
\hline $5148(1-3)^{\mathrm{e}}$ & 1995 & Kwale F.S., mycorrhiza trial & P. caribaea & $\mathrm{P}$ \\
\hline
\end{tabular}

For easy reference in the text, localities or areas sampled are listed. Haplotypes A, E and $\mathrm{P}$ stand for Afzelia-, Eucalyptus, and Pinus- RFLP types (see Figs 3,6). The numbers in brackets refer to individual basidiocarps collected in the mentioned area.

a F.S., Forest Station.

${ }^{\mathrm{b}}$ Haplotypes: A, Afzelia; E, Eucalyptus; P, Pinus.

c Sample comprises $(x)$ different basidiocarps collected within $10 \mathrm{~m}$ of the host tree.

a Sample comprises 10 different basidiocarps collected along a roadside bordering the eucalypt plantation.

e Samples comprises $(x)$ different basidiocarps, each collected beneath a different host tree within the plantation. 
samples giving no amplification or low amplification yield, DNA was extracted using a guanidinium buffer followed by DNA purification using GeneClean ${ }^{\circledR}$ glassbeads (Grube et al., 1995; Martin et al., 1997).

\section{PCR amplification and RFLP}

The ITS and IGS1 regions of the rDNA were amplified in duplicate by PCR using the primers ITS1/ITS4 and CNL12/5SA (Henrion et al., 1992) respectively, Taq DNA polymerase, and the buffer provided by the manufacturer (Appligène-Oncor, Illkirch, France) according to Henrion et al. (1994). Amplifications were carried out on a GeneAmp ${ }^{\mathbb{B}}$ PCR System 9600 (Perkin Elmer). The thermal cycling parameters were an initial denaturation at $94^{\circ} \mathrm{C}$ for $3 \mathrm{~min}$, followed by 30 cycles of denaturation at $94^{\circ} \mathrm{C}$ for $30 \mathrm{~s}$, annealing at $50{ }^{\circ} \mathrm{C}$ for $30 \mathrm{~s}$, and extension at $72{ }^{\circ} \mathrm{C}$ for $2 \mathrm{~min}$ with a final extension at $72{ }^{\circ} \mathrm{C}$ for $10 \mathrm{~min}$. Controls with no DNA were included in every series of amplification to test for the presence of contamination of reagents and reaction buffers. For RFLP analysis, one tenth of the amplified DNA was digested for between $1 \mathrm{~h}$ and overnight with 5-10 units of various restriction enzymes (Alu I, Hinf I, Mbo I, Rsa I) (Promega, BioLabs) according to the manufacturers' instructions. The amplification products were sizefractionated using a $1.5 \%$ regular agarose gel, whereas restriction fragments were separated using $2 \%$ composite agarose $(1.5 \%$ wide-range agarose and $0.5 \%$ regular agarose) or $10 \%$ polyacrylamide gels (Sambrook, Fritsch \& Maniatis 1989). Gels were stained with ethidium bromide, and photographed under u.v. light. Size standards were: $\phi$ X174 DNA, digested with Hae III, and BRL 100bp ladder.

\section{DNA sequencing and phylogenetic analyses}

ITS and IGS1 were amplified from two basidiocarps (collection nos 5105, 5110 and 5111) representative of each of the three haplotypes as described above. Double-stranded products were purified with QuickSpin ${ }^{\circledR}$ columns (Qiagen, Dusseldorf, Germany) and sequenced for both strands. The sequencing reactions were performed using the PRISM $^{\circledR}$ Ready Reaction Dye Primer Cycle Sequencing kit (Applied Biosystems, Foster City, CA, USA), Taq FS polymerase, and ITS1/ITS4 primers for ITS and CNL12/5SA for IGS1. The sequencing reaction products were analysed using a ABI model 373S DNA sequencer (Perkin Elmer Applied Biosystems) at the Sequencing Facilities of Laval University (Québec City, Québec, Canada). Raw sequence data were edited using Sequencher ${ }^{\mathbb{B}}$ (Gene Codes Corporation, Ann Arbor, MI) for Macintosh ${ }^{\circledR}$ and were deposited in the National
Center for Biotechnology Information (NCBI) databases under the following GenBank accession nos: no. 5105 ITS: AF003915, no. 5110 ITS: AF003914, no. 5111 ITS: AF003916, no. 5106 IGS1: AF061182, no. 5110 IGS1: AF061183, and no. 5111 IGS1: AF061184.

Search for sequence homology in the NCBI GenBank DNA database was carried out by Gapped BLAST (NCBI) (Altschul et al., 1997) WWW network services. Multiple sequence alignments were initially constructed with the aid of the MultAlin program (Corpet, 1988) on the WWW ProDom server (INRA, Toulouse, France): for the IGS1 sequences, and for the ITS sequences of the Kenyan Pisolithus (present study), P. tinctorius 441 collected under Eucalyptus citriodora in Brazil (GenBank accession no. U62666) (Carnero Diaz, Tagu \& Martin, 1997) and six Pisolithus isolates from New South Wales (Australia) [CS01 (GenBank accession no. AF004732), LJ07 (AF004733), R01 (AF004735), W15 (AF004736) W16 (AF004737) and WM01 (AF004734)] (Anderson et al., 1998). Owing to short hypervariable areas in the ITS sequences, sequence alignments were hand edited to improve alignments using the SeqPup (D. Gilbert, National Institutes of Health, Bethesda, MD, USA) sequence editor. The PAUP 3.1.1 program (Swofford, 1993) was used to construct parsimonybased trees. Both heuristic searches, using the nearest-neighbour interchange method, and branch and bound method searches were performed with similar results. All alignment gaps were treated as missing data. Validities of the clades were tested using bootstrap analysis (1000 iterations). Trees were drawn using PAUP 3.1.1 or using TreeView (version 1.3, written by Roderic D. M. Page, http/:// taxonomy.zoology.gla.ac.uk/rod/treeview.html).

RESULTS

\section{Basidiocarp collections}

Fifty-two basidiocarps of Pisolithus were collected at various times between 1993 and 1995 from areas within the localities listed in Table 1. Other localities where likely hosts grow were also searched for the fungus, without success. The three morphotypes therefore appear to have very restricted distributions in the lowland coast region in Kenya. The basidiocarps collected were all readily separated into the three morphotypes associated with particular host trees in Kenya on the basis of macroscopic characters (Fig. 1). The pine-associated taxon has large basidiocarps with a massive stipe, brown context, yellow external hyphae, large peridioles which extend into the stipe, and a thin dark, fragile exoperidium. The eucalypt-associated taxon has smaller basidiocarps with a less-massive stipe, bright orange/yellow stipe context, brown external hyphae, large peridioles not 

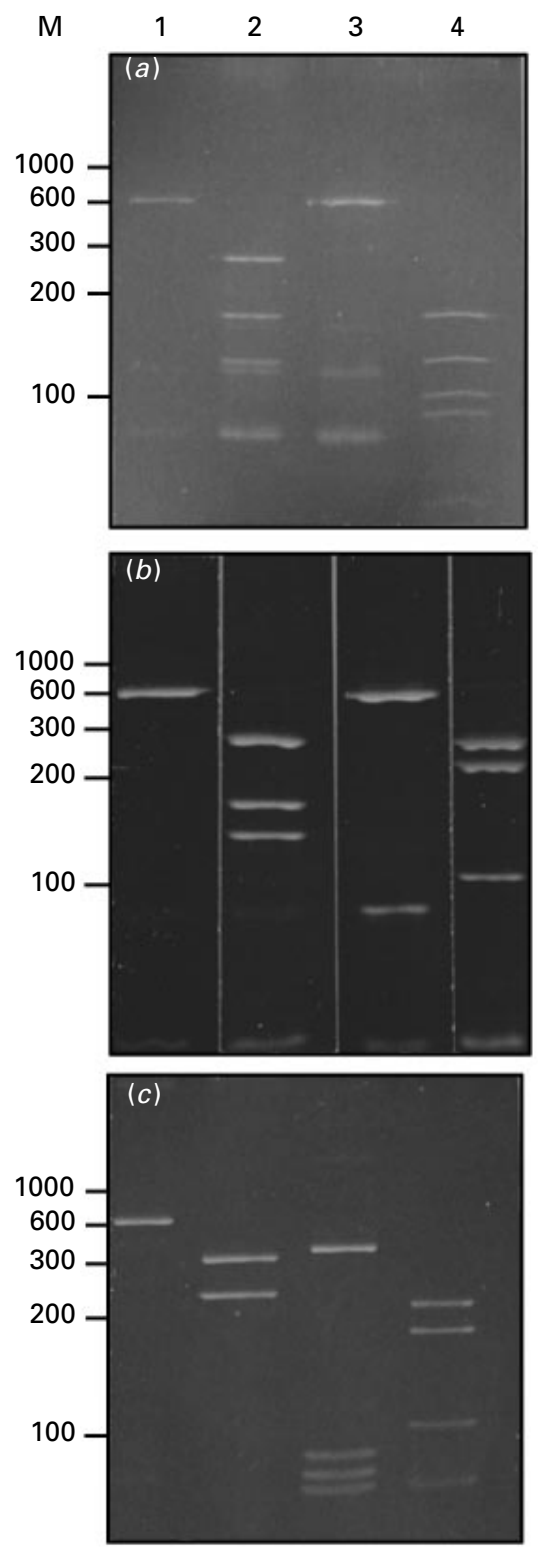

Figure 3. The amplified ITS and RFLP patterns of Pisolithus isolates associated with (a) Afzelia (= haplotype A), (b) Eucalyptus (= haplotype E), or (c) Pinus (= haplotype $\mathrm{P}$ ) in the lowland forests of the Coast Province of Kenya. Lane 1, uncut ITS; lane 2, 3, and 4: ITS cut with $M b o$ I, Alu I and Hinf I, respectively. 50-bp bands lanes $(a) 2$ and 3 are primers-dimers. Uncut ITS remains in lane 3. M, fragment size markers in bp. extending into the stipe, and a thin, pale, fragile exoperidium. The Afzelia-associated taxon has small basidiocarps with a slender stipe, brown context, brown external hyphae, small peridioles not extending into the stipe, and a thick, fragmenting exoperidium. The latter morphotype will be described elsewhere as a separate species (M. Honrubia, University of Murcia, Spain, pers. comm.).

\section{RFLP and sequence of ITS}

The rDNA ITS region of 52 basidiocarps of the three different morphotypes of Pisolithus were amplified with the conserved fungal primers ITS1 and ITS4. All basidiocarps of the Pinus, Eucalyptus and Afzelia morphotypes produced a single ITS band of c. 600 bp (Fig. 3). All basidiocarps presented restriction sites within the ITS region for each endonuclease used (Table 2), except for Rsa I which was excluded from further analysis. After digestion using endonucleases Mbo I, Alu I or Hinf I, each of the 52 basidiocarps produced one of three distinct rDNA haplotypes, referred to as $\mathrm{A}, \mathrm{E}$ or $\mathrm{P}$, with two to four restricted fragments per pattern (Fig. $3 a, b, c)$. These groups corresponded to collections sampled under Afzelia, eucalypt or pine, respectively. No restricted fragments were shared between these groups. Within each group, RFLP patterns of basidiocarps collected under the same tree (e.g. collection no. 5107 including basidiocarps 1, 2 and 3) or geographically-separated basidiocarps (up to $120 \mathrm{~km}$ for pine-associated isolates) (e.g. nos 5111/110 and 5148) were identical. RFLP patterns of basidiocarps coming from the same localities but collected in different years (Table 1) showed identical patterns.

Restriction digests of the amplified ITS revealed a variability indicative of striking sequence differences among the three distinct Pisolithus groups. Both strands of the amplified fragments, containing ITS1, $5.8 \mathrm{~S}$, and ITS2, from the three morphotypes/ haplotypes were sequenced (GenBank accession no. AF003914, AF003915 and AF003916) and aligned (Fig. 4) with known Pisolithus ITS sequences

Table 2. Size of the restriction fragments (in base pairs) of the rDNA ITS and IGS1 obtained using Alu I, Hinf I and Mbo I

\begin{tabular}{llll}
\hline Endonuclease & Afzelia-type & Eucalyptus-type & Pinus-type \\
\hline ITS & & & \\
Alu I & $85,120,480$ & 85,500 & $80,85,95,360$ \\
Hinf I & $95,110,140,190$ & $110,210,240$ & $85,120,160,220$ \\
Mbo I & $120,140,170,290$ & $120,170,280$ & 260,300 \\
IGS1 & & & \\
Alu I & 160,225 & 135,340 & 160,215 \\
Hinf I & 115,280 & $105,115,125,150$ & $110,145,160$ \\
Mbo I & 225,255 & $105,155,215$ & 220,250 \\
\hline
\end{tabular}




\begin{tabular}{|c|c|c|c|c|c|}
\hline & $\operatorname{TTS} 1$ & & & & \\
\hline 50 & C-GAGCCGT & GGGG & & & \\
\hline 801 & C-GAAAGGT & GCGGAGGGGG & GACCTTTGCC & --GGTCCTT & CGAAACCC \\
\hline W15 & TC-GAAAGGT & GCGGAGGGGG & A ACCTTTACC- & ---GGTCCTT & \\
\hline W16 & C-GAAACGT & GTGGAGGGGG & $=$ ACCTTTACT- & ---GGTCCTT & CCAAGCCC? \\
\hline IJJ0 7 & TCAGAAA- $-T$ & TCGAAGGGGG & GCGACGCGCT & TTGCCCCCTT & TTACCTCT \\
\hline - & $T C A-A A A A-T$ & TCGAAGGGGG & GCGACGCGCT & TCACCСССТT & TTACСТСТ \\
\hline 51. & TC-GAAA- $T$ & TCGAAGGGGG & GCGACGCGCT & TCGCCCCCTT & TTACCTCT \\
\hline & CC-GAGGCGT & -- GGAGGGGG & ACTCGTCCCT & CGAAGCCCTC & GTATACCT \\
\hline 51 & TCAGAGGGGA & TCGGA-GAGA & Т TCCGTTCCAC & CGAAGCCCTT & CGTTTACT \\
\hline nsus & tC gAaa gt & $=$ tcggAgGgGg & cc ttccc & geCCTt & cga cCt \\
\hline & & & & & \\
\hline $\operatorname{cs} 01$ & $\mathrm{TAC}$ & CT & $\mathrm{CA}$ & & GT? \\
\hline R01 & TACTTTGT & CCACA & GTGCACCCCG & TCGCGCGAG & GTTCTTCGG \\
\hline W15 & TGT & CCACA & GTGCACCCTG & TTCGCGTGAG & GTTCCTTCGG \\
\hline W16 & PTGT & CCACA & GTGCACCCTG & CGTGAG & TTCG \\
\hline LJ0 7 & $---c$ & $--\mathrm{AC}$ & $\mathrm{CGT}$ & CAAG & CCGG \\
\hline WT: 1 & $---C-$ & $--\mathrm{ACACC}---$ & CGTGTGCACC & SAAG & $\mathrm{CGG}$ \\
\hline 0 & $---\mathrm{C}-$ & -- & CACC & CAAG & TCCGGG \\
\hline & TGAC- & $--\mathrm{ACACC}---$ & CGTGTGCACC & CGTr & TTCGG \\
\hline 5111 & TTGAC- & $--\mathrm{ACA}$ & CGTGCACCCC & ATTCGCAAGG & GCCCTTCGGG \\
\hline nsu. & tt ac & ACACCtc & cgtg Cece & tt cgcgaG & GteC \\
\hline & 1 & & & & \\
\hline $\operatorname{cs} 01$ & $C C-T G$ & ICT & TCGTA & $\mathrm{GA}$ & ATGTAACCT. \\
\hline RO & CCCTG & CT & CG & $\mathrm{GA} 1$ & $\mathrm{ACCT}$ \\
\hline พ15 & ACCTG & TCT & CGI & TGT & АССТА \\
\hline W1 & ACCT & TCT & $\mathrm{CG} F$ & & $\mathrm{ACCT}$ \\
\hline LJ0 7 & GCA & GTG & $\mathrm{GA}=$ & $\mathrm{AGA}$ & ATGAA \\
\hline$M=0$ & GCA & $\mathrm{GTG}$ & $\mathrm{GA}$ & $\mathrm{GA}$ & $\mathrm{TGA}$ \\
\hline 5110 & - ССTGCGCA & GAG & GA. & TGT & ATGA \\
\hline & $\mathrm{A}-\mathrm{CC}---\mathrm{CT}$ & PTG & TAF & $\mathrm{GA}$ & GGT \\
\hline 5111 & A-CCCGCGCG & TTTCATCTCC & GACT--CGCA & $\mathrm{CAGA}$ & ATGTCGATAG \\
\hline nsus & 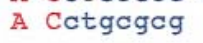 & $t c t t c$ & $\mathrm{cGcA}$ & TGT & ATGT a ta \\
\hline & 7 & & $.8 \mathrm{~S}$ & & \\
\hline $\operatorname{cs} 01$ & TGT--TGGA & $\mathrm{A}--\mathrm{A}$ & TAC & & GCT \\
\hline & TGTGT & $A--A$ & TA & & GGCT \\
\hline W15 & GCGT--TGGA & $-A$ & $\mathrm{TA}$ & $\mathrm{AG}$ & EGTC \\
\hline W1 & CGT--TGGA & $-\mathrm{A}$ & & & CT \\
\hline LJ07 & TTTG---- & CAA & $\mathrm{TA}$ & & GCT \\
\hline 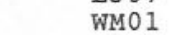 & 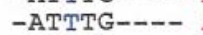 & AA & & & CT \\
\hline & -ATT-G---- & AAA & TAC & & GCT \\
\hline & -GGCGTCGGA & $\mathrm{CA}$ & & & GGCTC \\
\hline 5111 & CATTTGATAT & ATATATAAAA & TAC & GAT & TGGCT \\
\hline & gt gga & Aaa aa A & TACAACTTEC & GAT & СTCTTGGCTC \\
\hline & & & & & 250 \\
\hline C & $\mathrm{T}$ & & & & GCA \\
\hline & & & & & GCAG \\
\hline & $\mathrm{AT}$ & $\mathrm{CA}$ & & & GCAG \\
\hline & AT & & & & $G C A$ \\
\hline LJ0 7 & $\mathrm{AT}$ & & & & $\mathrm{CAC}$ \\
\hline & & & & & $T C$ \\
\hline & $\mathrm{AT}$ & & & & $\mathrm{CAC}$ \\
\hline & $\mathrm{AT}$ & & & & TC \\
\hline & $\mathrm{AT}$ & & & & GCA \\
\hline & GCATCGAT & GAAGgACGCA & GCGAATCGCG & ATG & ITGCA \\
\hline & & & & & \\
\hline & & & & & 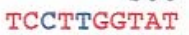 \\
\hline & & & & & \\
\hline & & & & & \\
\hline & & & & & \\
\hline & & & & & \\
\hline & & & & & $\mathrm{TC}$ \\
\hline & & & & & \\
\hline & & & & & TC \\
\hline & & & & & GTA \\
\hline לונרמ & TTG & $\mathrm{AA}^{\prime}$ & TC & & \\
\hline & & & & & 300 \\
\hline & & & & & $\mathrm{GCT}$ \\
\hline & TCCG & & & & A \\
\hline & C & & & & CT \\
\hline & TCCG & & & & $\mathrm{AC}$ \\
\hline & TCCGP & TTT & & & $\mathrm{CCT}$ \\
\hline & TCCGP & & & & $\mathrm{AC}$ \\
\hline & TCCG: & ITT & & & $\mathrm{CCT}$ \\
\hline & $\operatorname{TCCC}$ & & & $\mathrm{TCGA}$ & GGGT \\
\hline & & TTT & & TCAA & TT \\
\hline & & & & & \\
\hline
\end{tabular}

Figure 4. For legend see opposite. 


\begin{tabular}{|c|c|c|c|c|c|}
\hline & 351 & & & & $\begin{array}{r}400 \\
\text { GGAGGTCTGC }\end{array}$ \\
\hline Cs01 & TTTTGACTTT & GGTCGAAAAA & GCTTGGATTT & TGGAGTGTTG & $\begin{array}{l}\text { GGAGGTCTGC } \\
\text { GGAGGTCTGC }\end{array}$ \\
\hline R01 & TTTTGACTTT & GGTTGAAAAA & GCCCGGATTT & TGGAGTGTTG & GGAGGTCTGC \\
\hline W15 & TTTGACATT & GGTCGAAAAA & GCCTGGATTT & TGGAGTGT-G & GGAGGTCTG \\
\hline W16 & TTTGACATT & GGTCGAAAAA & GCCTGGATTT & TGGAGTGT-G & GGAGGTCTG \\
\hline LJO 7 & TTTGACTTG & GTT------- & $--------T$ & CGGACCGTTG & GGAG-TCTG \\
\hline WMOI & TTTGACTTG & GTT------ & $--------T$ & CGGACCGTTG & GGAG-TCTG \\
\hline 5110 & TTTGACTTG & GTT--ー---- & $-------T$ & CGGACCGTTG & GGAG-TCTC \\
\hline 5105 & TCTTTGCCTC & GGT-------- & $---------\mathrm{T}$ & TCGGACGTTG & GGAG-TCTG \\
\hline 5111 & TCTTGACTTC & GGTCGAA--- & GGCTCGGGTT & TGGACCGTTG & GGAG-TCTG \\
\hline onsensus & tTTgaCtT & GgT gaa & $g \quad g \quad t T$ & tgGa CGTtG & GGAG TCTG \\
\hline & 01 & & & & \\
\hline $\operatorname{Cs} 01$ & GGCGTGTCC & CGATCT---G & GGACTGCCAG & СТСТССТGAA & ATGCATT \\
\hline R01 & GGCA-GTCC & TGATCTTTTG & GGACTGCCAG & СTCTCCTGAA & ATGCATTAC \\
\hline W15 & GGC--GTCC & CGATCTT--G & GGACTGCCAG & CTCTCCTGAA & ATGCATTA \\
\hline W16 & AGGC--GTCC & CGATCTT--G & GGACTGCCAG & СТСTCCTGAA & ATGCATTA \\
\hline LJ0 7 & GGGCGACCCG & CСAT----- & GGGACGTCGG & СТСТССТGAA & ATGCATTA \\
\hline WM01 & GGGCGACCCG & ССАТ--- & GGGACGTCGG & СТСТССТGAA & ATGCATTA \\
\hline 5110 & GGGCGACCCG & CСАT------ & GGGACGTCGG & СТСТССТGAA & ATGCATTA \\
\hline 5105 & GGGCGACCCT & CTG----D- & GGGACGTCGG & СТСТССTGAA & ATGCATTA \\
\hline 5111 & GGGCGACGCA & T---ー---- & --GTCGTCGG & CTGAA & ATGCATTA \\
\hline onsensus & gGGCgac C & c at & ggg CGtCgG & СТСТССТGAA & ATGCATTa \\
\hline & 51 & & & & \\
\hline CS01 & GGAT & - - - - - - & -T-GCGACCA & GCCTCTTCGA & CGTCGT \\
\hline R01 & GGGATGGGTG & 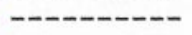 & -T-GCGACCA & ITCGA & TGTCGTAA \\
\hline พ15 & GGGATGGGCA & - - - - & -TTGCGACCA & GCCTCTTCGA & CGTCGTAZ \\
\hline W16 & GGGATGGGCA & - - - & -TTGCGAACA & GССTCTTCGA & CGTCGTAA \\
\hline LJ07 & GGGTGGGC-- & $---------G$ & CGTGACCCCT & GCCCСTTC-- & GACGTCAT \\
\hline WM01 & GGGTGGGC-- & $---------G$ & CGTGACCCCT & GCCCCTTC-- & GACGTCAT \\
\hline 5110 & GGGTGGGC-- & $-------G$ & CGTGACCCCT & GCCCСTTC-- & GACGTCATI \\
\hline 5105 & GGTGGGCGTG & CAAGCCTTTG & CACGGTGCCA & GCCTCTTC-- & TCGT \\
\hline 5111 & GGAGGGCATG & САAGTCTT-G & CTTGGCACCA & GССTCTCCCC & GGCGTCATI \\
\hline nsus & GGg gGggtg & g & cttG aCCa & GCCtCTtC & ggcgtcat \\
\hline & 01 & & & & \\
\hline $\operatorname{cs} 01$ & GT & GGACT-GTGA & .-- & $T-C C$ & $\mathrm{CCCCC}-$ \\
\hline R01 & CGATCG & GGACT-GTGA & GC---- & ---ТTтTтC & CCCCC--T \\
\hline W15 & CGATCC & GGACTTGTGA & GC-------- & ---ТТТСССС & $\mathrm{CCC}----\mathrm{T}$ \\
\hline W16 & CGATCG & GGACTTGTGA & GC-------- & ---ТTТССС & CCCCCCCT \\
\hline LJ0 7 & TGATCC & GGGCGAACGA & ACCG---- & $---T G T C C C G$ & СGCTTCTCI \\
\hline WM01 & TGATCG & GGGCGAACGA & ACCG------ & $---T G T C C C G$ & CGCTTCTC \\
\hline 5110 & TGATCC & GGGCGAACGA & ACCG.-- & $\mathrm{CCCG}$ & МТTC? \\
\hline 5105 & TGATCGTCGT & GGGCTAGGGG & CGTC------ & ---ТTТСССА & TGCTTCCT \\
\hline 5111 & TGATCG & GGGCTGTCCA & GCTGCAAGGG & ACATGTCCCA & TGCTTCTCC \\
\hline onsensus & tGATCGTCGt & GGgCt g ga & ge & TtTccC & cgCttc $t$ \\
\hline & 5 & & & & $25 \mathrm{~s}$ \\
\hline $\mathrm{CS} 01$ & $T$ & TG-------- & -- & --- & -TTGAAG \\
\hline & GCTTTGCTAT & TG------- & $----\infty$ & --- & -T-GAAGG \\
\hline W15 & АСTTTC & TG------- & - - - - - - & - - - - - - - & -GTGAAGG \\
\hline W16 & AT & TG------- & 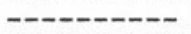 & $---1-1-1$ & $\triangle A G$ \\
\hline J0 7 & $\mathrm{GA}$ & GGGGAGCTTT & CGTGCTCTTC & тсССтTGССC & TT \\
\hline 01 & AGA & GGGGAGCTTT & CGTGCTCTTC & TCC-TTGCCC & TTC \\
\hline 10 & ACTCGG & GGGGAGCTAT & CGTGCTCTTC & TCC-TTGCCC & \\
\hline & ACTCGTGCGA & 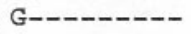 & CGCGTCCGTG & TGGCTCGCCT & TTCAAAG \\
\hline 5111 & ACTTTGCGAG & C--------- & --ССТСТССТ & GGGCTCTGCG & TTCGAAC \\
\hline onsensus & acrttgc a & g & & t $c$ & ttcgAAGG \\
\hline & & & & & \\
\hline $\operatorname{cs} 01$ & A & TCAGGT & & & \\
\hline & ACCTCAAA & TCAGGT & & & \\
\hline W15 & TGACCT & TCAGGT & & & \\
\hline W16 & TGACCTCAAA & TCAGGT & & & \\
\hline LJ0 7 & TGACCT & TCAGGG & & & \\
\hline & TGACCTCAAA & TCAGGT & & & \\
\hline 5110 & TGACCTCAAA & TCAGGT & & & \\
\hline 5105 & CGACCTCAAA & TCAGGT & & & \\
\hline 5111 & TGACCTCAAA & TCAGGT & & & \\
\hline nsus & CTCAAA & TCAGGT & & & \\
\hline
\end{tabular}

Figure 4. Multiple sequence alignment of the ITS region of basidiocarps of Pisolithus associated to Eucalyptus camaldulensis, Pinus caribaea, or Afzelia quanzensis in Kenya, together with Pisolithus ITS sequences available in the NCBI database. no. 5105 (GenBank accession no. AF003915), no. 5110 (accession no. AF003914), no. 5111 (accession no. AF003916), basidiocarps associated with A. quanzensis, E. camaldulensis, and P. caribaea, respectively; 441, vegetative mycelium of $P$. tinctorius 441 associated with Eucalyptus citriodora in Brazil; CS01 (GenBank accession no. AF004732), LJ07 (AF004733), R01 (AF004735), W15 (AF004736), W16 (AF004737) and WM01 (AF004734), isolates of Pisolithus collected in New South Wales (Australia) (Anderson et al., 1998; with kind permission). -, gap resulting from insertion/deletion.

(Anderson et al., 1998, Carnero-Diaz et al., 1997). The Pisolithus ITS sequences were all clearly related to each other. The actual length of the corresponding fragment was $589-627 \mathrm{bp}$, also containing a part of the $3^{\prime}$-end of the $18 \mathrm{~S}$ rDNA and the $5^{\prime}$-end of the $28 \mathrm{~S}$ rDNA. Typically, a high degree of similarity 


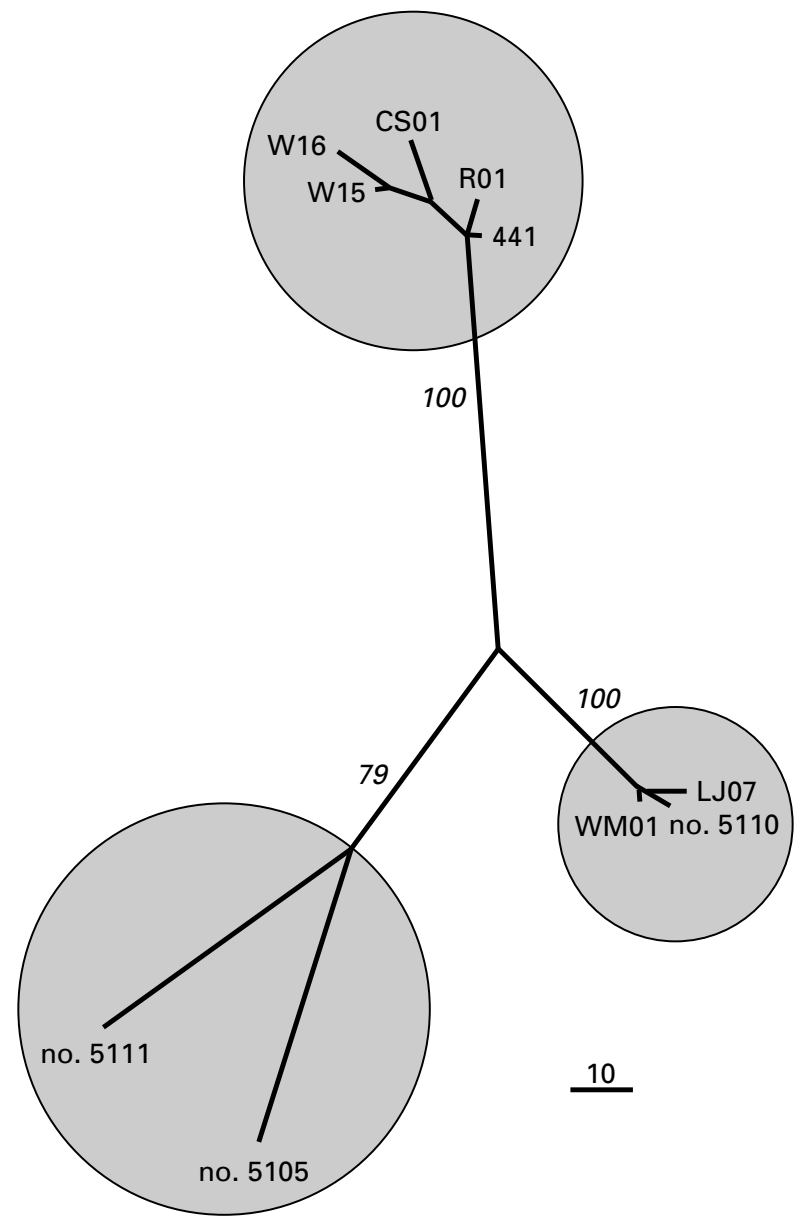

Figure 5. Radial parsimony tree of ITS sequences of Pisolithus isolates. The tree was constructed from the sequence alignment data set shown in Figure 4. The illustration is one of three equally parsimonious trees of length 329 which were found using PAUP 3.1.1 to perform a heuristic search with simple addition. Numerical values, shown along the stem of each supported clade, are those deriving from 1000 replicates of heuristic parsimony bootstrap analysis. The scale bar on the bottom right indicates the length of 10 steps in the tree. Outlines and shading indicate particular groupings of ITS referred to in the text.

was present within the $194 \mathrm{bp}-5.8 \mathrm{~S}$ rDNA region in all the Pisolithus collections ( $<95 \%$ ) (Fig. 4) and the Pisolithus 5.8S showed a high similarity with basidiomycetous ITS sequences deposited in the NCBI DNA database (data not shown).

The ITS1 and ITS2 sequences of the three distinct Kenyan Pisolithus morphotypes differed by several insertions/deletions and base substitutions, but conservation patterns with phylogenetic diagnostic value (Hershkovitz \& Zimmer, 1996), could be easily identified. The multiple sequence alignment (Fig. 4) indicated that isolates no. 5110 (eucalypt-associated morphotype), and LJ07 and WM01 from NSW (Australia) had 98\% sequence homology with each other, but only $85 \%$ homology with the other isolates. Their sequence are characterized by the presence of a CT-rich insertion in the $3^{\prime}$-end of the ITS2 region. Similarly, isolates CS01,
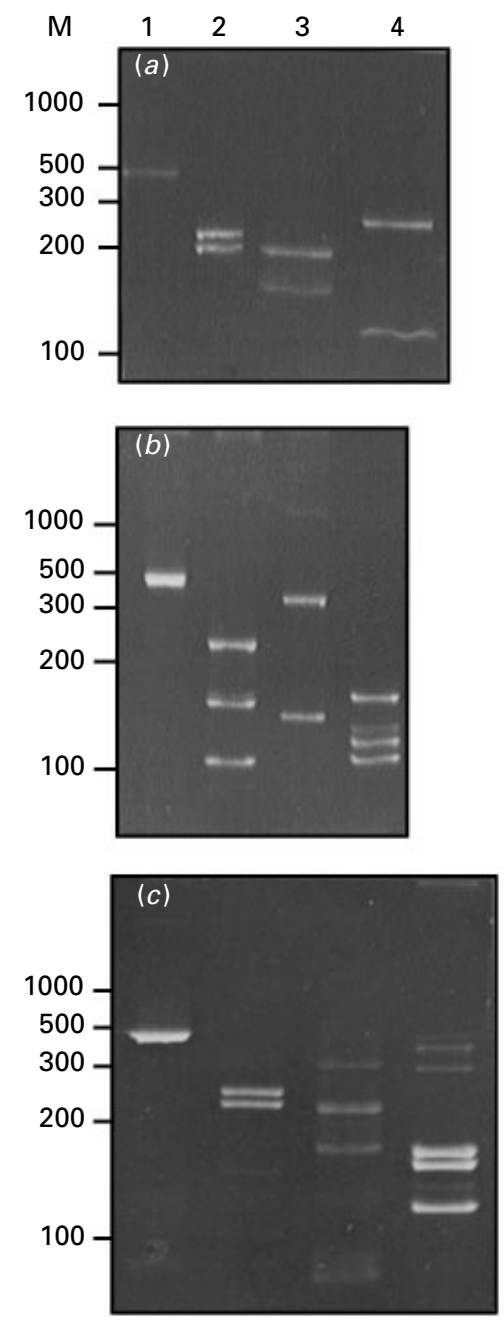

Figure 6. The amplified IGS1 and RFLP patterns of Pisolithus isolates associated with (a) Afzelia (= haplotype A), (b) Eucalyptus (= haplotype E), or (c) Pinus (= haplotype $\mathrm{P}$ ) in the lowland forests of the Coast Province of Kenya. Lane 1, uncut IGS1; lane 2, 3, and 4: ITS cut with Mbo I, Alu I and Hinf I, respectively. M, fragment size markers in bp. Partial digestion products are visible above $300 \mathrm{bp}$ in $(c) 4$.

R01, W15, W16 from NSW and P. tinctorius 441 from Brazil showed a high degree of sequence homology, being 95-97\% homologous. The ITS sequences of Afzelia- (no. 5105) and Pine- (no. 5111) associated isolates were divergent with each other and strikingly divergent from other investigated Pisolithus isolates.

Equally weighted, unordered parsimony analysis of the data set of all ITS sequences resulted in three equally parsimonious trees (differences between the trees were due to branch swapping of haplotypes). The strict consensus radial tree (Fig. 5), deriving from 1000 iterations of heuristic parsimony bootstrap analysis, shows the relationships among the 10 ITS sequences. It supports the clear differentiation of the three major groups revealed by sequence pairwise comparison. The various Pisolithus groups were supported by very strong branches (79-100\% of 1000 bootstrap iterations). 


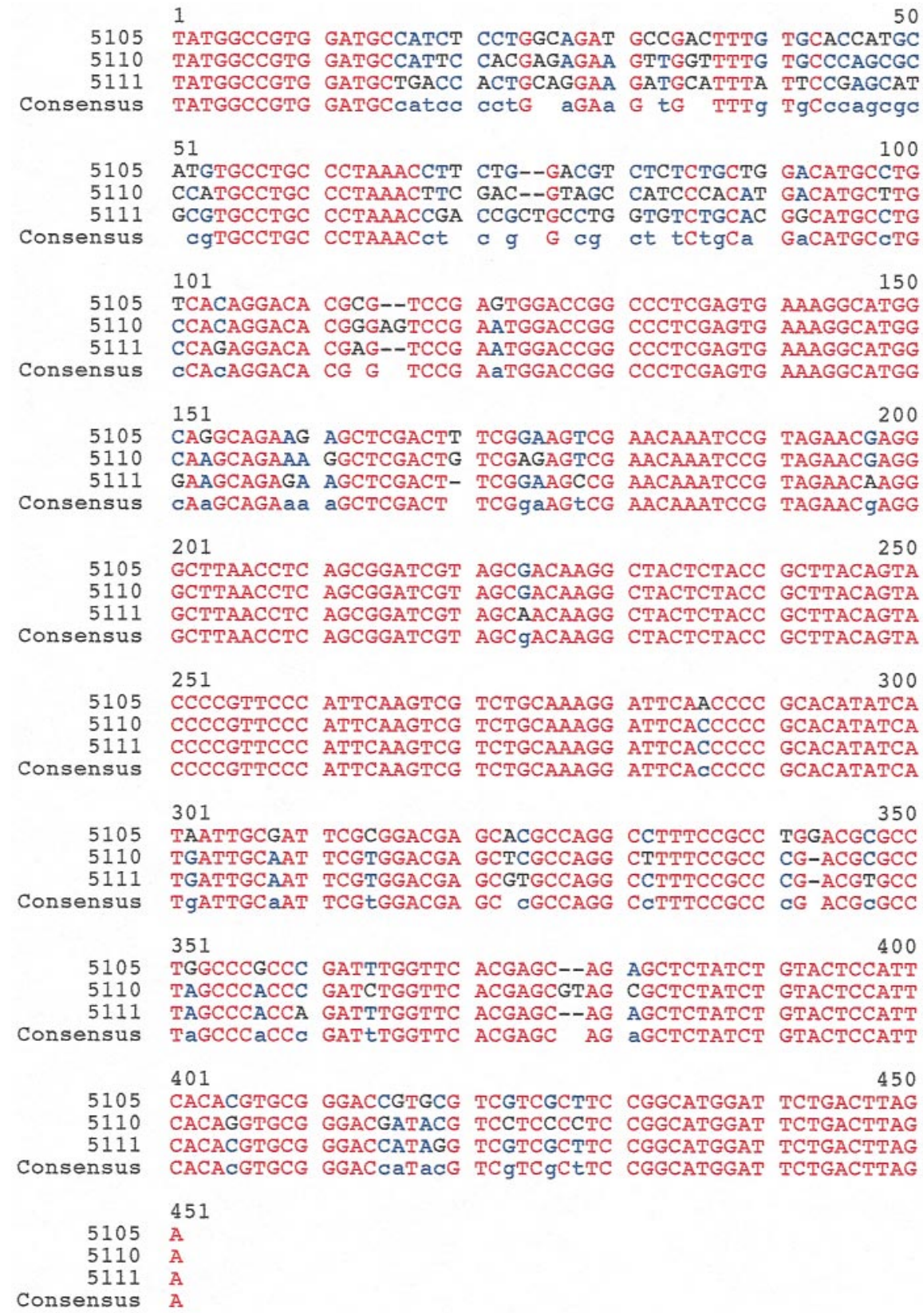

Figure 7. Multiple sequence alignment of IGS1 of basidiocarps of Pisolithus associated to Eucalyptus camaldulensis (5110; accession no. AF0061183), Pinus caribaea (5111, accession no. AF0061184) and Afzelia quanzensis (5106, GenBank accession no. AF0061182). -, gap resulting from insertion/deletion.

\section{RFLP and sequence of IGS}

The basidiocarps were further examined by PCR/ RFLP of the rDNA IGS, a rDNA region known as highly variable in fungi (Henrion et al., 1992, 1994; Apel \& Gordon, 1996; Selosse et al., 1996). All basidiocarps of the Pinus-, Eucalyptus- and Afzeliamorphotypes produced a single IGS band of $450 \mathrm{bp}$ (Fig. 6). Heteroduplex formation resulting from rDNA heterozygosity (Selosse et al., 1996) was not observed in the amplification of Pisolithus rDNA IGS. Three distinct restriction patterns, with two to four restricted fragments per pattern, were detected using Alu I, Hinf I, and Mbo I (Fig. 6; Table 2). The clustering of basidiocarps was identical to the one achieved by PCR/RFLP of the rDNA ITS. In both analyses, the 52 basidiocarps formed three clusters which correspond to the three morphotypes of Pisolithus. By contrast, RFLPs of IGS1 of isolates, collected over a wide geographical scale (100$120 \mathrm{~km}$ ), were identical within each morphotype/ haplotype.

Both strands of the amplified IGS1 were sequenced (GenBank accession no. AF001182, AF0061183 and AF0061184) and aligned (Fig. 7). These sequences were clearly related to each other. The actual length of the corresponding fragment was 446-449 bp, also containing a part of the $3^{\prime}$-end of the $25 \mathrm{~S}$ rDNA and the $5^{\prime}$-end of the $5 \mathrm{~S}$ rDNA. The aligned sequences indicated that isolates nos 5110 
(eucalypt-associated), and 5111 (eucalypt-associated) and 5105 (Afzelia-associated) had $21 \%$ sequence divergence with each other.

\section{DISCUSSION}

Because collections within the Pisolithus taxon exhibit considerable variability in basidiocarp and basidiospore morphology, it is widely thought that Pisolithus is a complex of evolutionarily independent biological species (Bronchart et al., 1975; Kope \& Fortin 1990; Burgess et al., 1995; Watling et al., 1995). Various methods based on the PCR have been proposed to characterize ectomycorrhizal fungi (Gardes et al., 1991; Henrion et al., 1992) and to examine phylogenetic relationships in the various taxa (Bruns, White \& Taylor, 1991). Direct sequencing of genes coding for nuclear and mitochondrial rRNA genes and intergenic spacers amplified by PCR (Bruns et al., 1989; Bruns \& Szaro, 1992; Kretzer et al., 1996; Selosse et al., 1996) and RFLP analysis of these PCR-amplified sequences (Gardes et al., 1991; Henrion et al., 1992, 1994) have been used to characterize ectomycorrhizal fungi at the intraspecific and interspecific phylogenetic levels. In the present investigation, we have used this approach to investigate genetic and phylogenetic relationships between the morphotypes of Pisolithus found in plantations and woodlands of the Coast Province of Kenya.

In the area studied, host association appeared to be a key feature in the clustering of Pisolithus isolates since all of the basidiocarps, isolated under a specific host plant ( $A$. quanzensis, $P$. caribaea, or $E$. camaldulensis), but ranking from subregional to local area scale, produced identical rDNA patterns and sequences. They showed no obvious correlation with geographical origin. This lack of genetic variability within highly polymorphic DNA regions, such as the IGS1, has been confirmed by using microsatellite-primed PCR (data not shown) and suggests that little breeding occurs between Pisolithus associated with pine and eucalypt plantations and the indigenous morphotype associated with a native tree (Afzelia) in forest reserves even when basidiocarps of different morphology/haplotype occur in close proximity $(\sim 10-100 \mathrm{~m})$. The variation in basidiocarp morphology and the degree of host specificity (Ivory et al., 1996), together with the present genetic analysis suggest that eucalypt-compatible and pine-compatible strains of Pisolithus have been introduced to Kenya and now persist in a few pine and eucalypt plantations.

The sequence analysis of the rDNA ITS and IGS1 have confirmed that the Pisolithus types in the study area are genetically highly divergent. The three groups formed by analysis of sequence polymorphism of rDNA spacers correlated very well with basidiocarp morphotypes and host range (Ivory et al., 1996). The estimated pairwise distance among Pisolithus ITS sequences (up to $20 \%$ ) is extensive when compared to that found in some other fungal species (1-10\%) (Gardes et al., 1991; Hibbett et al., 1995; Bruns et al., 1991; Hseu et al., 1996). Comparable levels of sequence divergence between distinct species and species groups within the basidiomycetes (e.g. Lentinus; Hibbett et al. (1995)) and ascomycetes (e.g. Cenococcum geophilum; Lobuglio, Rogers \& Wang (1991)) have been interpreted as indicating significant evolutionary divergence within these species.

Similarly, the high degree of rDNA ITS divergence among Pisolithus from Kenya (present study) and Australia (Anderson et al., 1998) suggests that we are dealing with a complex of evolutionarily independent biological species. Although highly variable at the interspecific level, the ITS region contains conserved patterns and could be used to diagnose phylogenetic relationships (Hershkovitz \& Lewis, 1996; Hershkovitz \& Zimmer, 1996). A parsimony analysis of the data set of all ITS sequences of Pisolithus available in DNA databases was therefore performed. The phylogenetic analysis clearly separated a group of isolates including the eucalypt-associated no. 5110 (Kenya), LJ07 and WM01 (Australia) from the cluster containing other Australian isolates (W16, W15, CS01, R01) and no. 441 from Brazil. These findings confirm and extend a study, based on RAPD and ITS sequence analyses, of NSW Pisolithus (Anderson et al., 1998). Separation of the eucalypt-associated isolates on two strongly supported branches $(100 \%$ bootstrap values from 1000 iterations) indicates that these two groups might represent two different species. Basidiocarp and basidiospore morphology of the Australian isolates CS01, R01, W15 and W16 conformed to Cunningham's description (Cunningham, 1942) of P. tinctorius (Anderson et al., 1998). This suggests that the group, including isolates CS01, R01, W15, W16 and no. 441, probably represents $P$. tinctorius, whereas the other cluster (no. 5110, LJ07 and WM01) represents another, probably undescribed Pisolithus species. Isolates of Pisolithus associated to Afzelia (no. 5105) or pine (no. 5111) were related, but widely separated from other clades. They might also represent additional species, but more isolates need to be included in future studies to fully resolve the genetic heterogeneity within these two Pisolithus types. Interestingly, ITS sequence of Pinus-associated basidiocarps (no. 5111) found in Kenya was identical to the sequence of isolates of Pisolithus collected beneath pine species on different continents suggesting a common origin for this morphotype (Dell et al., unpublished).

It appears that distinct evolutionary lineages occur amongst the $P$. tinctorius populations world-wide (Bronchart et al., 1975; Calogne \& Demoulin, 1975; Burgess et al., 1995; Watling et al., 1995; Anderson 
et al., 1998; present study). An analysis of rDNA ITS sequence variation amongst these world-wide populations would be useful for exploring the phylogenetic relationships existing between these lineages.

\section{ACKNOWLEDGEMENTS}

The above study forms part of a joint research programme conducted by INRA-Nancy, Oxford Forestry Institute, Kenya Forestry Research Institute, and Universidad de Murcia, which is entirely funded by the EU project TS3CT92-0124. We would like to thank Céline Di Battista (INRA-Nancy) for her assistance in PCR typing during the initial phase of this project, Bernie Dell (Murdoch University) for critical reading of an early version of the manuscript and his timely suggestions, and John Cairney (University of Western Sydney) for providing ITS sequences of Australian Pisolithus before publication. Discussions with Linus Mwangi (KEFRI) have been very helpful and appreciated.

\section{REFERENCES}

Altschul SF, Madden TL, Schaffer AA, Zhang J, Zhang Z, Miller W, Lipman DJ. 1997. Gapped BLAST and PSIBLAST: a new generation of protein database search programs. Nucleic Acids Research 25: 3389-3402.

Anderson IC, Chambers SM, Cairney JWG. 1998. Molecular determination of genetic variation in Pisolithus isolates from a defined region in New South Wales, Australia. New Phytologist 138: 151-162.

Appel DJ, Gordon TR. 1996. Relationships among pathogenic and nonpathogenic isolates of Fusarium oxysporum based on the partial sequence of the intergenic spacer region of the ribosomal DNA. Molecular Plant-Microbe Interactions 9: 125-138.

Bronchart R, Calogne FD, Demoulin V. 1975. Nouvelle contribution à l'étude de l'ultrastructure de la paroi sporale des Gastéromycètes. Bulletin Trimestriel de la Société Mycologique de France 91 : 232-246.

Bruns TD, Szaro TM. 1992. Rate and mode differences between nuclear and mitochondrial small-subunit rRNA genes in mushrooms. Molecular Biology and Evolution 9: 836-855.

Bruns TD, Fogel R, White TJ, Palmer JD. 1989. Accelerated evolution of a false-truffle from a mushroom ancestor. Nature 339: $140-142$.

Bruns TD, White TJ, Taylor JW. 1991. Fungal molecular systematics. Annual Review of Ecology and Systematics 22: 525-564.

Burgess T, Dell B, Malajczuk N. 1994. Variation in mycorrhizal development and growth stimulation by 20 Pisolithus isolates inoculated onto Eucalyptus grandis W. Hill ex Maiden. New Phytologist 127: 731-739.

Burgess T, Malajczuk N, Dell B. 1995. Variation in Pisolithus based on basidiome and basidiospore morphology, culture characteristics and analysis of polypeptides using 1D-SDSPAGE. Mycological Research 99: 1-13.

Cairney JWG, Chambers SM. 1997. Interactions between Pisolithus tinctorius and its hosts: a review of current knowledge. Mycorrhiza 7: 117-131.

Calogne FD, Demoulin V. 1975. Les Gastéromycètes d'Espagne. Bulletin Trimestriel de la Société Mycologique de France 91 : 247-292.

Carnero Diaz ME, Tagu D, Martin F. 1997. Ribosomal DNA internal transcribed spacers to estimate the proportion of Pisolithus tinctorius and Eucalyptus globulus RNAs in ectomycorrhiza. Applied and Environmental Microbiology 63: 840-843.

Corpet F. 1988. Multiple sequence alignment with hierarchical clustering. Nucleic Acids Research 16: 10881-10890.

Cunningham GH. 1942. The Gasteromycetes of Australia and New Zealand. Dunedin, New Zealand: John McIndoe.

Garbaye J, Delwaulle JC, Diangana D. 1988. Growth response of eucalypts in the Congo to ectomycorrhizal inoculation. Forest Ecology and Management 24: 151-157.

Gardes M, White TJ, Fortin JA, Bruns TD, Taylor JW. 1991. Identification of indigenous and introduced symbiotic fungi in ectomycorrhizae by amplification of nuclear and mitochondrial ribosomal DNA. Canadian Fournal of Botany 69: 189-190.

Grube M, Depriest PT, Gargas A, Hafellner J. 1995. DNA isolation from lichen ascomata. Mycological Research $\mathbf{9 9}$ $1321-1324$

Henrion B, Le Tacon F, Martin F. 1992. Rapid identification of genetic variation of ectomycorrhizal fungi by amplification of ribosomal RNA genes. New Phytologist 122: 289-298.

Henrion B, Chevalier G, Martin F. 1994. Typing truffle species by PCR amplification of the ribosomal DNA spacers. Mycological Research 98: 37-43.

Hershkovitz MA, Lewis LA. 1996. Deep-level diagnostic value of the rDNA-ITS region. Molecular Biology and Evolution 13: 1276-1295

Hershkovitz MA, Zimmer EA. 1996. Conservation patterns in angiosperm rDNA ITS2 sequences. Nucleic Acids Research 24 2857-2867.

Hibbett DS, Fukusama-Nakai Y, Tsuneda A, Donoghue MJ. 1995. Phylogenetic diversity in shiitake inferred from nuclear ribosomal DNA sequences. Mycologia 87: 618-638.

Ho I. 1987. Comparison of eight Pisolithus tinctorius isolates for growth rate, enzyme activity, and phytohormone production. Canadian Fournal of Forestry Research 17: 31-35.

Hseu RS, Wang HH, Wang HF, Moncalvo JM. 1996. Differentiation and grouping of isolates of the Ganoderma lucidum complex by random amplified polymorphic DNA-PCR compared with grouping on the basis of internal transcribed spacer sequences. Applied and Environmental Microbiology 62 : $1354-1363$.

Ivory MH. 1987. Diseases and disorders of pines in the tropics. Overseas Research Publication 31, Overseas Development Administration, London/Oxford Forestry Institute, Oxford.

Ivory MH, Honrubia M, Mburu BK, Mwangi LM. 1996. Putative ectomycorrhizal fungi from native and exotic forests in Kenya. In: Azcon-Aguilar C, Barea JM, eds. Mycorrhizas in Integrated Systems from Genes to Plant Development. Brussels, Luxembourg: Office for official publications of the European Communities, COST Report, 125-127.

Kope HH, Fortin JA. 1990. Germination and comparative morphology of basidiospores of Pisolithus arhizus. Mycologia 82: $350-357$

Kretzer A, Li Y, Szaro T, Bruns TD. 1996. Internal transcribed spacer sequences from 38 recognized species of Suillus sensu lato: phylogenetic and taxonomic implications. Mycologia $\mathbf{8 8}$ 776-785.

Lamhamedi MS, Fortin JA, Kope HH, Kropp BR. 1990. Genetic variation in ectomycorrhiza formation by Pisolithus arhizus on Pinus pinaster and Pinus banksiana. New Phytologist 115: 689-697.

Lobuglio KF, Rogers SO, Wang CJK. 1991. Variation in ribosomal DNA among isolates of the mycorrhizal fungus Cenococcum geophilum. Canadian Fournal of Botany 69: 2331-2343.

Malajczuk N, Grove TS, Bougher TS, Dell B, Gong Minquin. 1994. Ectomycorrhizas and nutrients - their importance to eucalypts in China. Brown AG, eds. Australian Tree Species Research in China. Canberra, Australia: Australian Centre for International Agricultural Research, 132-139.

Malajczuk N, Lapeyrie F, Garbaye J. 1990. Infectivity of pine and eucalypt isolates of Pisolithus tinctorius on roots of Eucalyptus urophylla in vitro 1. Mycorrhiza formation in model systems. New Phytologist 114: 627-631.

Martin F, Costa G, Delaruelle C, Diez J. 1997. Genomic fingerprinting of ectomycorrhizal fungi by microsatelliteprimed PCR. In: Varma A, Hock B, eds. Mycorrhiza Manual. Springer Lab Manual Berlin: Springer-Verlag, 463-474.

Marx DH. 1977. Tree host range and world distribution of the ectomycorrhizal fungus Pisolithus tinctorius. Canadian Fournal of Microbiology 23: 217-223.

Marx DH. 1980. Variability in ectomycorrhizal development and growth among isolates of Pisolithus tinctorius as affected by source, age, and re-isolation. Canadian Fournal of Forest Research 11: 168-174.

Marx DH, Bryan WC, Cordell CE. 1977. Survival and growth of 
pine seedlings with Pisolithus ectomycorrhizae after two years on reforestation sites in North Carolina and Florida. Forest Science 16: 363-373.

Mehmann B, Egli S, Braus GH, Brunner I. 1995. Coincidence between molecularly or morphologically classified ectomycorrhizal morphotypes and fruitbodies in a spruce forest. In: Stocchi V, Bonfante P, Nuti M, eds. Biotechnology of Ectomycorrhizae. Molecular Approaches. New York: Plenum Press, 41-52.

Sambrook J, Fritsch EF, Maniatis T. 1989. Molecular Cloning. A Laboratory Manual, 2nd edn. New York: Cold Springer Harbor Laboratory Press.

Selosse M-A, Costa G, Di Battista C, Le Tacon F, Martin F.
1996. Meiotic segregation and recombination of the intergenic spacer of the ribosomal DNA in the ectomycorrhizal basidiomycete Laccaria bicolor. Current Genetics 30: 332-337.

Swofford DL. 1993. PAUP: Phylogenetic analysis using parsimony, version 3.1.1. Computer program distributed by the Illinois Natural History Survey, Champaign, IL, USA.

Tonkin CM, Malajczuk N, McComb JA. 1989. Ectomycorrhizal formation by micropropagated clones of Eucalyptus marginata inoculated with isolates of Pisolithus tinctorius. New Phytologist 111: 209-24.

Watling R, Taylor A, Lee SS, Sims K, Alexander IJ. 1995. A rainforest Pisolithus: its taxonomy and ecology. Nova Hedwigia 61: 417-429. 